\title{
The Natural Product Avrainvillamide Binds to the Oncoprotein Nucleophosmin
}

\author{
Jeremy E. Wulff, Romain Siegrist, and Andrew G. Myers ${ }^{\star}$ \\ Contribution from the Department of Chemistry and Chemical Biology, Harvard University, \\ Cambridge, Massachusetts 02138
}

\begin{abstract}
Here we present evidence that (+)-avrainvillamide, a naturally occurring alkaloid with antiproliferative effects, binds to the nuclear chaperone nucleophosmin, a proposed oncogenic protein that is overexpressed in many different human tumors. Among other effects, nucleophosmin is known to regulate the tumor suppressor protein p53. A synthetic biotin-avrainvillamide conjugate, nearly equipotent to the natural product in inhibiting the growth of cultured T-47D cells, was used for affinity-isolation of a protein identified as nucleophosmin by MS sequencing and Westernblotting. Affinity-isolation of nucleophosmin was inhibited in the presence of iodoacetamide (10 $\mathrm{mM})$, free (+)-avrainvillamide $(100 \mu \mathrm{M})$, and a series of closely related structural analogues of $(+)$ avrainvillamide, the latter with inhibitory effects that appear to correlate with measured growthinhibitory potencies. Using fluorescence microscopy, a synthetic dansyl-avrainvillamide conjugate was observed to localize within the nucleoli and the cytosol of treated cancer cells. Site-directed mutagenesis of each of the three cysteine residues of a truncated nucleophosmin co-expressed with native nucleophosmin in COS-7 cells revealed that the mutation cys ${ }^{275} \rightarrow \mathrm{ala}^{275}$ effectively and uniquely reduced affinity-isolation of the truncated protein, suggesting that avrainvillamide targets cys $^{275}$ of nucleophosmin. Finally, we show that treatment of adhered LNCaP or T-47D cells with (+)-avrainvillamide leads to an increase in cellular p53 concentrations, and that siRNA-promoted depletion of nucleophosmin in a population of HeLa S3 cells leads to increased sensitivity of that population toward apoptotic death upon treatment with (+)-avrainvillamide. Although potentially desirable as lead compounds for the development of novel anti-cancer therapies, non-peptidic, synthetic small molecules that bind to nucleophosmin have not been described, prior to this report.
\end{abstract}

\section{Introduction}

(+)-Avrainvillamide (1, Figure 1) is a natural product of fungal origin with antiproliferative effects in a number of different cultured human cancer cells. ${ }^{1,2}$ In prior research, in an effort to determine the molecular basis of these effects, we employed the structurally simpler, less potent analogue $\mathbf{2}$, containing the 3 -alkylidene- $3 H$-indole 1 -oxide (unsaturated nitrone) core of $\mathbf{1}$, and its biotin conjugate $\mathbf{3}$ (Figure 1) to isolate and identify potential protein-binding partners from cancer-cell lysates. ${ }^{3}$ Four proteins were thus identified (heat-shock protein 60 (HSP60), exportin 1 (XPO1), glutathione reductase (GR), and peroxiredoxin 1 (PRX1)), all containing active-site or known reactive cysteine residues. In each case, protein binding was inhibited in the presence of iodoacetamide, suggesting that the binding was cysteine-mediated, consistent with the earlier proposal that (+)-avrainvillamide and its analogues function as electrophiles by reversible, covalent nucleophilic (thiol) addition to the unsaturated nitrone functional group. 4 
Our prior studies revealed that (+)-avrainvillamide (1) has the capacity to bind one or more proteins in vitro, but did not establish to what degree the protein-small molecule interactions we had identified might contribute to the apoptotic events induced by (+)-avrainvillamide. Here, in studies using a series of molecules that more closely mimics the natural product $\mathbf{1}$ both structurally and in their growth-inhibitory activities (compounds $\mathbf{4}$ and $\mathbf{5}$, Figure 1, and compounds 8 - 11, Figure 4), we determine that (+)-avrainvillamide has the heretofore unrecognized capacity to bind to the nucleolar phosphoprotein nucleophosmin (NPM1.1, B23, numatrin, NO38), and provide evidence that this interaction contributes to the observed antiproliferative effects of (+)-avrainvillamide in cultured cancer cells. Site-directed mutagenesis experiments support the proposal that (+)-avrainvillamide binds specifically to cysteine-275 of nucleophosmin, a residue near the $C$-terminus and one of three free cysteines in the native protein.

Nucleophosmin is a multifunctional protein that is overexpressed in many human tumors and has been implicated in cancer progression. ${ }^{5}$ Primarily a nucleolar protein, nucleophosmin is widely expressed in metazoans, binds to many different proteins as well as nucleic acids as it shuttles between the nucleus and the cytoplasm, ${ }^{6}$ and is frequently mutated in cancer cells. Genetic modifications of the C-terminal region of nucleophosmin are common in acute myeloid leukemia (AML) and are believed to be tumorigenic. ${ }^{7}$ More than half of anaplastic large-cell lymphomas (ALCLs) express a nucleophosmin-anaplastic lymphoma kinase fusion protein arising from a chromosomal translocation event, which is proposed to lead to the onset of cancer. Different nucleophosmin fusion proteins have been identified in other cancers, and a 35-amino acid carboxyl-truncated form, NPM1.2, arising from alternative splicing, is associated with radiation insensitivity in HeLa cells and displays aberrant nuclear-cytosolic trafficking. $., 9,10,11$ Nucleophosmin is also deleted in certain tumors, although this is less common than its overexpression in tumor cells. ${ }^{12}$ The roles of nucleophosmin in cancer are complex, and a detailed understanding of these is presently evolving, as discussed in several recent reviews, ${ }^{13}$ but a significant factor is believed to be its ability to regulate the tumor suppressor protein p53. ${ }^{14}$ Among other findings, RNA silencing of nucleophosmin or disruption of its function by the addition of a small nucleophosmin-binding peptide ${ }^{15}$ leads to increased expression of $\mathrm{p} 53 .{ }^{16}$ Loss of $\mathrm{p} 53$ function (owing to mutation, deletion, or hDM2 overexpression) is one of the most common features of transformed cells, and novel approaches to restore cellular p53 function are widely sought as these have demonstrated potential for tumor regression in vivo. 17,18

While synthetic small molecules that bind to nucleophosmin and thereby inhibit its participation in protein-protein and/or protein-nucleic acid interactions might serve as potential leads for the development of novel anti-cancer therapies, ${ }^{13}$ such compounds are largely unknown. ${ }^{19-23}$

\section{Results and Discussion}

By modifying one coupling partner in a late-stage, two component coupling reaction (step 15 of a 17-step synthetic sequence), ${ }^{24}$ we have prepared more than 30 analogues of avrainvillamide to date. For this study, we made use of the dansyl- and biotin-conjugated probes 4 and 5 (Figure 1), respectively, and the analogues 8 - 11 of Figure 4 (see Supporting Information for details of their synthesis). We first studied the antiproliferative effects of the conjugates $\mathbf{4}$ and $\mathbf{5}$ and found that both compounds inhibited the growth of T-47D (breast cancer) cells with potencies similar to the natural product (Figure 1). Although the biotin conjugate (5) was somewhat less potent than the dansyl conjugate (4) in inhibiting the growth of $\mathrm{LNCaP}$ (prostate cancer) cells, it did provide a $\mathrm{GI}_{50}$ value similar to values measured with the structurally simpler analogue $\mathbf{2}$ and its biotin conjugate $\mathbf{3}$, compounds we had previously studied and reevaluated herein as controls. ${ }^{3}$ Compounds $\mathbf{6}$ and $\mathbf{7}$ (Figure 1), which lack the 
unsaturated nitrone function but contain the dansyl and biotin groups, respectively, as well as the lipophilic tethering groups, were inactive in our assays, suggesting that neither the tethers nor the reporter groups of the active probes $\mathbf{3}-\mathbf{5}$ contribute substantially to the observed antiproliferative activities of these compounds.

Fluorescence microscopy studies conducted with the dansyl-conjugate $\mathbf{4}$ revealed partial localization of the probe in the nucleoli of HeLa S3 (cervical cancer) and T-47D cells, in addition to a somewhat dispersed cytoplasmic distribution (Figure 2 and Supporting Information). 25

To identify potential binding proteins, populations of healthy (adherent) T-47D cells were treated with the newly synthesized biotin conjugate 5 or the structurally simpler biotincontaining probe $\mathbf{3}$, previously studied. As a control, a separate population of cells was treated with the biotin derivative 7 , which lacks the unsaturated nitrone function. The treated cells were incubated with probe or control for $90 \mathrm{~min}$ at $37^{\circ} \mathrm{C}$, then were harvested, washed and lysed. The individual lysates were exposed to an agarose resin to remove nonspecific binding proteins. After centrifugation, the supernatants were then exposed to a streptavidin-agarose resin. This resin was collected by centrifugation and washed. Bound proteins were released by heat-denaturation, separated by SDS-PAGE, and analyzed by LC-MS/MS and Western-blot.

Nucleophosmin was initially identified by MS/MS sequencing of a pool of proteins of broad molecular weight range obtained using the structurally simpler probe $\mathbf{3}$. The analysis was complicated by the presence of a number of non-specific binding proteins, including structural proteins such as actin, tubulin, and myosin, as well as a number of biotinylated proteins, but the identification of nucleophosmin in probe-treated but not control protein samples was reproducible. With this information, MS/MS sequencing of a protein pool of somewhat narrower molecular weight range obtained using the more complex probe 5 also revealed a large peptide fragment with an amino acid sequence corresponding to nucleophosmin (see Supporting Information for details).

The presence of nucleophosmin in probe-derived (but not control) protein samples was readily confirmed by Western-blotting experiments (Figure 3A, compare lane 2 with lane 3, and lane 4 with lane 5). Strikingly, probe 5 more effectively bound nucleophosmin than did the structurally simpler and less potent probe $\mathbf{3}$, even when a three-fold higher concentration of $\mathbf{3}$ was used relative to $\mathbf{5}$ (compare lane 2 of Figure $3 \mathrm{~A}$ with lane 4 ). This provided the first evidence that nucleophosmin might have a greater affinity for (+)-avrainvillamide (1) than for analogues with lesser potency in antiproliferative assays, such as $\mathbf{2}$ and $\mathbf{3}$. We found that as little as $100-500 \mathrm{nM}$ concentrations of the biotinylated probe 5 were sufficient to afford detectable levels of nucleophosmin in affinity-isolation experiments from whole-cell lysates of T-47D cells (Figure 3B). Competition experiments established that binding of nucleophosmin to the biotin-conjugated probe $\mathbf{5}$ in both nuclear-enriched and whole-cell lysates from T-47D cells was inhibited in the presence of a 10-fold higher concentration of free (+)-avrainvillamide (1) (Figure 3C, compare lane 2 with lane 1), was not diminished in the presence of a 10-fold higher concentration of (-)-avrainvillamide (ent-1) (Figure 3C, lane 3 ), and was somewhat diminished in the presence of a 10-fold higher concentration of the micromolar inhibitor 2 (Figure 3C, lane 4). Binding of nucleophosmin to probe 5 was substantially reduced in the presence of a 1000-fold excess of iodoacetamide (Figure 3D), consistent with the proposal that protein binding to $\mathbf{1}$ is cysteine-mediated. ${ }^{3}$

A more definitive series of competition experiments was conducted using a structurally similar series of analogues of (+)-1 spanning a 10-fold range of growth-inhibitory activities in T-47D and LNCaP cell lines $(\mathbf{8}-\mathbf{1 1}$, Figure 4$)$. The most active of these compounds $(\mathbf{8})$ was nearly as potent as avrainvillamide in antiproliferative assays. The differing antiproliferative activities 
of compounds $\mathbf{8}-\mathbf{1 1}$ were reasoned to be more likely attributable to differential target protein binding than to differential cell permeabilities and/or stabilities, although this was by no means certain. As shown by the data in Figure 4, we observed a correlation between the antiproliferative activity of a compound and its ability to inhibit the affinity-isolation of nucleophosmin. Thus, binding of nucleophosmin to the probe $\mathbf{5}$ was inhibited essentially equivalently by (+)-1 and the nearly equipotent analogue 8 (compare lanes 2 and 3, Figure 4), was only partially inhibited by the 3 -fold less potent inhibitor 9 (lane 4, Figure 4), and was least effectively inhibited by the micromolar inhibitors $\mathbf{1 0}$ and $\mathbf{1 1}$ (lanes 5 and 6 of Figure 4). 26 This type of correlation was not observed with other proteins we had identified from our previous affinity-isolation experiments. For example, affinity-isolation of both exportin-1 and peroxiredoxin- 1 from T-47D cells using the probe $\mathbf{5}$ is inhibited equally by $(+)-\mathbf{1}$ and ent-1, although the latter is $\sim 3$-fold less potent as an inhibitor of T-47D cell-growth. ${ }^{27,28}$ In contrast, inhibition of probe 5 -nucleophosmin binding required the use of a $\sim 5$-fold higher concentration of ent-1 versus 1 (500 $\mu \mathrm{M}$ and $100 \mu \mathrm{M}$, respectively) (data not shown).

Wild-type nucleophosmin contains three free cysteine residues. Two of these, cys ${ }^{21}$ and cys ${ }^{104}$, are located in the $\mathrm{N}$-terminal domain, which serves as the locus for a dynamic $\mathrm{pH}$-and ion-sensitive self-aggregation process leading to the formation of oligomeric complexes. 29 The $C$-terminal domain, which includes cys ${ }^{275}$, mediates interactions with $\mathrm{p} 53$, hDM2, and several known DNA and RNA sequences. ${ }^{13}$ To identify whether a particular cysteine residue is involved in nucleophosmin binding, we prepared mutant constructs replacing in turn each cysteine residue with alanine, then expressed these mutant proteins in COS-7 cells. The mutant constructs were chosen to code for a naturally occurring 30 isoform of nucleophosmin with a 29 amino acid-deletion in the central, basic region of the peptide sequence (NPM1.3, see Figure 5; plasmids encoding both NPM1.1 and NPM1.3 are commercially available ${ }^{31}$ ) in order to allow us to distinguish the mutant nucleophosmin proteins from the background native protein (NMP1.1). ${ }^{32}$

Following expression, the COS-7 cells were harvested and lysed. Affinity-isolation experiments were conducted as described above, using $1 \mu \mathrm{M}$ biotinylated probe $\mathbf{5}$; nucleophosmin was detected by Western-blot analysis after separation by SDS-PAGE. As evident from the data of Figure 6, NPM1.3 is readily distinguished from NPM1.1, and appears to be more effectively bound in the affinity-isolation procedure than the native form of the protein (NPM1.1). Whereas deletion of cys ${ }^{21}$ or cys ${ }^{104}$ had little effect on affinity-isolation of NPM1.3 (compare lanes 3 or 4 of Figure 6 with lane 2), deletion of cys ${ }^{275}$ greatly reduced affinity-isolation of NPM1.3 (compare lane 5 of Figure 6 with lane 2), suggesting that cys ${ }^{275}$ mediates binding to the probe. The outcome of this experiment might well have been less definitive, given that nucleophosmin is known to self-associate to form oligomeric complexes; 29 this may explain the faint band for NPM1.3 that is present in lane 5 for the cys $^{275} \rightarrow$ ala $^{275}$ mutated protein.

To further address the question of whether the binding of avrainvillamide to nucleophosmin may contribute to the observed antiproliferative effects of the natural product, we transiently depleted nucleophosmin in HeLa S3 cells by transfection with an siRNA targeting nucleophosmin, then compared the ability of (+)-avrainvillamide to induce apoptosis in the siRNA-modified cell line relative to a control population mock-transfected with a null siRNA (Figure 7A). We found that the cells reduced in nucleophosmin exhibited enhanced sensitivity to (+)-avrainvillamide (1), providing a correlation between the antiproliferative effects of avrainvillamide and levels of the protein nucleophosmin.

Disruption of nucleophosmin function has been shown to lead to an increase in cellular p53 concentrations. ${ }^{16}$ We therefore investigated the effects of (+)-avrainvillamide-treatment on p53 levels in cultured cancer cells. Populations of healthy (adhered) T-47D or LNCaP cells 
were treated with varying concentrations of (+)-avrainvillamide (1) for $24 \mathrm{~h}$. Following cell lysis and adjustment of concentrations to achieve uniform amounts of total protein, we analyzed for p53 by Western-blot. We observed a substantial increase in cellular p53 following the addition of as little as $500 \mathrm{nM}(+)$-avrainvillamide (1, see Figure 7B). This increase occurs prior to apoptosis-related changes such as translocation of nucleophosmin to the cytosol (see Figure 7B), cleavage of poly(ADP-ribose) polymerase (PARP), activation of caspase-3 or release of cytochrome-C from the mitochondrion (data not shown). Up-regulation of the tumor control-protein p53 is well known to promote apoptosis and is associated with tumor regression. 34

\section{Conclusion}

(+)-Avrainvillamide (1) binds to a number of proteins in cancer cell lysates that contain reactive cysteine residues, as we have shown, and therefore may interact with more than one cellular protein in vivo. The discovery that avrainvillamide binds to nucleophosmin is significant, as non-peptidic small-molecules that bind this oncoprotein are virtually unknown. The apparent correlation we observe between the measured antiproliferative activities of a series of structurally similar analogues of avrainvillamide with their effectiveness in inhibiting the binding of nucleophosmin to the activity-based probe $\mathbf{5}$ is noteworthy. This, coupled with the finding that depletion of nucleophosmin by RNA silencing leads to increased sensitivity of HeLa S3 cells toward apoptotic cell death in the presence of (+)-avrainvillamide (1), suggests that the interaction of $\mathbf{1}$ and its analogues with cellular nucleophosmin may play a role in the observed antiproliferative effects of the compound class. The observation that affinity-isolation of nucleophosmin with the natural product-like probe $\mathbf{5}$ is inhibited in the presence of iodoacetamide is consistent with prior results that implicate avrainvillamide as an electrophile with a particular affinity for cysteine residues. Results of site-directed mutagenesis experiments, modifying in turn each of the three free cysteine residues of nucleophosmin, reveal that binding of the natural product is likely mediated by the specific residue cys ${ }^{275}$ near the $\mathrm{C}$-terminus of the protein, which is associated with binding to nucleic acids and proteins such as p53 and hDM2.

\section{Experimental Section}

\section{A. Materials}

(+)-Avrainvillamide (1), (-)-ent-avrainvillamide (ent-1), and compounds $\mathbf{2 , 3}$ and $\mathbf{7}$ were synthesized as previously described. ${ }^{3,24}$ The syntheses of compounds $\mathbf{4}-\mathbf{6}$ and $\mathbf{8 - 1 1}$ are described in the Supporting Information. LNCaP, T-47D, and HeLa-S3 cells were purchased from ATCC. COS-7 cells were a gift from the Alan Saghatelian group. Bradford reagent and Laemmli loading buffer ( $2 \mathrm{X}$ concentration) were purchased from Sigma Aldrich.

Antiproliferative assays were conducted in pre-sterilized 96-well flat-bottomed plates from BD Falcon. Solutions of resazurin were purchased from Promega as the CellTiter-Blue Cell Viability Assay kit, and were used according to the manufacturer's instructions. Sodium dodecylsulfate polyacrylamide gel electrophoresis (SDS-PAGE) was performed using precast Novex Tris-glycine mini gels (10\%, 12\% or 4-20\% gradient, Invitrogen). Benchmark prestained protein markers were purchased from Invitrogen. Electrophoresis and semi-dry electroblotting equipment was purchased from Owl Separation Systems. Nitrocellulose membranes were purchased from Amersham Biosciences. A mouse monoclonal antibody to nucleophosmin (B23) was purchased from Santa Cruz Biotechnology (sc-32256). A rabbit polyclonal antibody to peroxiredoxin 1 was purchased from GeneTex (GTX15571). Rabbit polyclonal antibodies to exportin 1 and p53 were purchased from Santa Cruz Biotechnology (XPO1: sc-5595; p53: sc-6243). An Alexafluor-647 goat anti-mouse secondary antibody, together with Image-iT FX Signal Enhancer blocking solution, was purchased from Invitrogen (A31625). Western-blot detection was performed using the SuperSignal West Pico 
Chemiluminscence kits (including goat anti-rabbit-HRP and goat anti-mouse-HRP conjugates) from Pierce. Western blots were visualized using CL-XPosure X-ray film from Pierce, or were imaged on an AlphaImager. Streptavidin-agarose and Sepharose 6B were purchased from Sigma Aldrich. Protein bands were visualized using the Novex Colloidal Blue staining kit from Invitrogen, and were analyzed at the Taplin Biological Mass Spectrometry Facility (Harvard University). Yo-Pro iodide was purchased from Invitrogen.

\section{B. Instrumentation}

Molecular Dynamics multiwell plate readers were used to obtain absorbance and fluorescence measurements (absorbance: SPECTRAmax PLUS 384, fluorescence: SPECTRAmax GEMINI XS). Data was collected using SOFTmax PRO v. 4.3 (Molecular Dynamics), and was manipulated in Excel (Microsoft). The XLfit4 plugin (IDBS software) running in Excel was used for curve fitting. Fluorescence microscopy experiments were performed using a Zeiss upright microscope, equipped with $355 \mathrm{~nm}, 488 \mathrm{~nm}, 543 \mathrm{~nm}$ and $633 \mathrm{~nm}$ lasers. Flow cytometry experiments were performed on an LSR II flow cytometer (BD Biosciences).

\section{General Experimental Remarks}

All cell-culture work was conducted in a class II biological safety cabinet. All buffers were filter-sterilized $(0.2 \mu \mathrm{m})$ prior to use. Antiproliferative assays and other operations requiring the handling of nitrone species were carried out in the dark to prevent the occurrence of photochemical rearrangement reactions. Compounds 1-11 were stored at $-80^{\circ} \mathrm{C}$, either as frozen $5 \mathrm{mM}$ stocks in DMSO, or as dry solids (100- $\mu \mathrm{g}$ portions).

\section{Cell-Culture}

Cells were cultured in RPMI $1640^{35}$ (Mediatech) containing 10\% fetal bovine serum (Hyclone), $10 \mathrm{mM}$ HEPES, and $2 \mathrm{mM}$ L-glutamine. Cells were grown in BD Falcon tissue culture flasks with vented caps.

\section{E. Preparation of Solutions}

RIPA buffer: $50 \mathrm{mM}$ Tris.HCl, pH 7.35; $150 \mathrm{mM} \mathrm{NaCl} ; 1$ mM EDTA; $1 \%$ Triton X-100; $1 \%$ Sodium deoxycholate; $0.1 \%$ SDS; $1 \mathrm{mM}$ PMSF; $5 \mu \mathrm{g} / \mathrm{mL}$ aprotinin; $5 \mu \mathrm{g} / \mathrm{mL}$ leupeptin; 200 $\mu \mathrm{M} \mathrm{Na}_{3} \mathrm{VO}_{4} ; 50 \mathrm{mM} \mathrm{NaF}$. Tris buffer: $50 \mathrm{mM}$ Tris. $\mathrm{HCl}$, pH 7.38; Wash buffer: $50 \mathrm{mM}$ Tris. $\mathrm{HCl}, \mathrm{pH} 7.6 ; 75 \mathrm{mM} \mathrm{NaCl} ; 0.5 \mathrm{mM}$ EDTA; 0.5\% Triton X-100; 0.5\% Sodium deoxycholate; $0.05 \%$ SDS. Sucrose-hypotonic buffer: $25 \mathrm{mM}$ Tris. $\mathrm{HCl}, \mathrm{pH} 6.8 ; 250 \mathrm{mM}$ sucrose; $0.05 \%$ digitonin; $1 \mathrm{mM}$ DTT; $1 \mathrm{mM}$ PMSF; $5 \mu \mathrm{g} / \mathrm{mL}$ aprotinin; $5 \mu \mathrm{g} / \mathrm{mL}$ leupeptin; $200 \mu \mathrm{M} \mathrm{Na} 3 \mathrm{VO}_{4} ; 50 \mathrm{mM} \mathrm{NaF}$. Apoptosis-detection buffer: $100 \mathrm{nM}$ Yo-Pro iodide; $1.5 \mu \mathrm{M}$ propidium iodide; $1 \mathrm{mM}$ EDTA; $1 \%$ BSA in PBS (Mediatech). For abbreviations, see Supporting Information.

\section{F. Preparation of Resins}

A $400-\mu \mathrm{L}$ aliquot of streptavidin-agarose suspension was transferred to a $1.7-\mathrm{mL}$ centrifuge tube. Wash buffer $(1.0 \mathrm{~mL})$ was added, and the resulting slurry was mixed for $5 \mathrm{~min}$ at $4{ }^{\circ} \mathrm{C}$. The resin was isolated by centrifugation $\left(12000 \times \mathrm{g}, 2 \mathrm{~min}, 4^{\circ} \mathrm{C}\right)$, and the supernatant was discarded. The resin was washed twice with $1.0 \mathrm{~mL}$ wash buffer (each wash: 5 min mixing at $4{ }^{\circ} \mathrm{C}$, followed by $2 \mathrm{~min}$ centrifugation at $12000 \times \mathrm{g}, 4^{\circ} \mathrm{C}$ ), then was suspended in $800 \mu \mathrm{L}$ wash buffer and mixed thoroughly prior to use. A $400-\mu \mathrm{L}$ aliquot of Sepharose-6B suspension was treated identically, and used to remove nonspecific binding proteins where indicated. 


\section{G. Antiproliferative Assays}

LNCaP and T-47D cells were grown to approximately $80 \%$ confluence, then were trypsinized, collected, and pelleted by centrifugation $(10 \mathrm{~min}$ at $183 \times \mathrm{g})$. The cell pellet was suspended in fresh medium, and the concentration of cells was determined using a hemacytometer. The cell suspension was diluted to $1.0 \times 10^{5}$ cells $/ \mathrm{mL}$. A multichannel pipette was used to load the wells of a 96-well plate with $100 \mu \mathrm{L}$ per well of the diluted cell suspension. The plates were incubated for $24 \mathrm{~h}$ at $37{ }^{\circ} \mathrm{C}$ under an atmosphere of $5 \% \mathrm{CO}_{2}$. The following day, 100- $\mu \mathrm{g}$ portions of the nitrone samples were removed from the freezer, thawed, and dissolved in filter-sterilized DMSO to a concentration of $5 \mathrm{mM}$. A $6.5-\mu \mathrm{L}$ aliquot of the nitrone solution was dissolved in $643.5 \mu \mathrm{L}$ of medium to achieve a working concentration of $50 \mu \mathrm{M}$. Serial dilutions were employed to generate a range of different concentrations for analysis. Finally, $100-\mu \mathrm{L}$ aliquots of this diluted nitrone solution were added to the wells containing adhered cells, resulting in final assay concentrations of up to $25 \mu \mathrm{M}$. The treated cells were incubated for $72 \mathrm{~h}$ at $37^{\circ} \mathrm{C}$ $\left(5 \% \mathrm{CO}_{2}\right)$. To each well was added $20 \mu \mathrm{L}$ of CellTiter-Blue reagent, and the samples were returned to the incubator. Fluorescence ( $560 \mathrm{~nm}$ excitation $/ 590 \mathrm{~nm}$ emission) was recorded on a 96-well plate reader following a 4.0-h incubation period $\left(37{ }^{\circ} \mathrm{C}, 5 \% \mathrm{CO}_{2}\right)$. Percent growth inhibition was calculated for each well, based upon the following formula: Percent growth inhibition $=100 \times\left(\mathrm{S}-\mathrm{B}_{0}\right) /\left(\mathrm{B}_{\mathrm{t}}-\mathrm{B}_{0}\right)$; where $\mathrm{S}$ is the sample reading, $\mathrm{B}_{\mathrm{t}}$ is the average reading for a vehicle-treated population of cells at the completion of the assay, and $\mathrm{B}_{0}$ is the average reading for an untreated population of cells at the beginning of the assay. Each analogue was run a minimum of eight times, over a period of at least two weeks. For each compound, 14 separate concentrations were used in the assay, ranging from $25 \mu \mathrm{M}$ to $8 \mathrm{nM}$. The average inhibition at each concentration was plotted against concentration, and a curve fit was generated. To eliminate positional effects (e.g., cell samples in the center of the plate routinely grew more slowly than those near the edge), the data was automatically scaled to ensure that the curves showed no inhibition at negligible concentrations of added compound. Such a precaution was found to generate more consistent data from week to week, without affecting the final results. Final $\mathrm{GI}_{50}$ values reflect the concentrations at which the resulting curves pass through 50 percent inhibition.

\section{H. Fluorescence Microscopy Experiments}

HeLa S3 cells adhered onto number 1.5 glass coverslips were exposed to medium containing $0 \mathrm{mM}$ (vehicle control), $1 \mathrm{mM}$ or $3 \mathrm{mM}$ probe 4 . All samples contained $0.06 \%$ DMSO. The samples were incubated $\left(37^{\circ} \mathrm{C}, 5 \% \mathrm{CO}_{2}\right)$ for $2 \mathrm{~h}$, fixed in methanol at $-20^{\circ} \mathrm{C}$, and permeablized in $0.1 \%$ Triton X-100. The sample treated with $1 \mathrm{mM}$ probe 4 was exposed to $150 \mathrm{~mL}$ of primary antibody solution $(0.5 \mathrm{~mL}$ of mouse anti-B23 in $499.5 \mathrm{~mL}$ PBS $)$, then to $150 \mathrm{~mL}$ of secondary antibody solution $(0.5 \mathrm{~mL}$ of Alexafluor-647 goat anti-mouse in $499.5 \mathrm{~mL}$ PBS). All samples were washed with PBS and mounted with $20 \mathrm{~mL}$ Mowiol mounting mixture (containing $0.1 \%$-phenylene diamine) prior to analysis. Full experimental details and additional data are provided in the Supporting Information.

\section{Identification of Nucleophosmin by LC-MS/MS}

Refer to the Supporting Information.

\section{J. Affinity-Isolation Experiments}

Full details of affinity-isolation experiments in live cells and cellular lysates (including competitive binding experiments) are provided in the Supporting Information. For experiments in live cells, adhered T-47D cells were treated with probes $(\mathbf{3}$ or $\mathbf{5})$ or controls $(\mathbf{1}, \mathbf{2}$ and/or $\mathbf{7})$ in cell-culture medium for $90 \mathrm{~min}$ at $37{ }^{\circ} \mathrm{C}$ under an atmosphere of $5 \% \mathrm{CO}_{2}$. The medium (including any detached cells) from each sample was transferred to a 50-mL centrifuge tube. The cells were rinsed with $10 \mathrm{~mL}$ PBS, which was added to the centrifuge tubes. Adhered cells 
were detached from the culture flasks by trypsinization $\left(10 \mathrm{~min}, 37^{\circ} \mathrm{C}, 5 \mathrm{~mL}\right.$ per flask, $0.05 \%$ trypsin, $0.53 \mathrm{mM}$ EDTA). Fresh medium $(10 \mathrm{~mL})$ was added, and the resulting suspension was added to the centrifuge tubes, along with a $5 \mathrm{~mL}$ PBS rinse. The samples were centrifuged (10 $\min$ at $183 \times \mathrm{g}$ ), and the supernatant was discarded. The cells were resuspended in $1 \mathrm{~mL}$ of PBS, transferred to a $1.7-\mathrm{mL}$ centrifuge tube, and centrifuged again $(5 \mathrm{~min}$ at $500 \times \mathrm{g})$. The supernatant was discarded, and the cells were washed twice with $1 \mathrm{~mL}$ of PBS. The washed cells were cooled on ice, then lysed by addition of $500 \mu \mathrm{L}$ per sample ice-cold RIPA buffer. The samples were mixed end-over-end for $1 \mathrm{~h}$ at $4{ }^{\circ} \mathrm{C}$ with occasional vortexing, then $500 \mu \mathrm{L}$ per sample Tris buffer was added. The samples were centrifuged $\left(12000 \times \mathrm{g}, 10 \mathrm{~min}, 4^{\circ} \mathrm{C}\right)$, and insoluble material was removed with a pipette tip. The lysates were transferred to fresh $1.7-\mathrm{mL}$ centrifuge tubes. Each individual sample lysate was treated with $50 \mu \mathrm{L}$ of washed, well-suspended, two-fold diluted Sepharose resin. The resulting slurry was mixed for $6 \mathrm{~h}$ at 4 ${ }^{\circ} \mathrm{C}$, then was centrifuged $\left(12000 \times \mathrm{g}, 2 \mathrm{~min}, 4^{\circ} \mathrm{C}\right)$. The supernatant was transferred to a clean $1.7-\mathrm{mL}$ centrifuge tube.

For in vitro experiments, probe $\mathbf{5}$ was added (on ice, in the dark), in the presence or absence of competitors, to a $384-\mu \mathrm{L}$ aliquot of cellular lysate (see Supporting Information for preparation of the lysates) at $1.5 \mathrm{mg} / \mathrm{mL}$ total protein (Bradford determination ${ }^{36}$ ). The resulting samples ( $400 \mu \mathrm{L}$ final volume, containing $4 \%$ DMSO) were mixed end-over-end in the dark for $4 \mathrm{~h}$ at $4{ }^{\circ} \mathrm{C}$.

Each sample was treated with two 30- $\mu \mathrm{L}$ aliquots of washed, well-suspended, two-fold diluted streptavidin-agarose resin. The resulting slurry was mixed for $15 \mathrm{~h}$ at $4{ }^{\circ} \mathrm{C}$, then was centrifuged $\left(12000 \times \mathrm{g}, 10 \mathrm{~min}, 4^{\circ} \mathrm{C}\right)$. The supernatant was discarded. The collected resins were washed with wash buffer at $4{ }^{\circ} \mathrm{C}$, then with Tris buffer at $4{ }^{\circ} \mathrm{C}$, then twice with Tris buffer at $23{ }^{\circ} \mathrm{C}$. Each wash consisted of 10 min mixing, followed by 10-min centrifugation (either $12000 \times \mathrm{g}$ at $4{ }^{\circ} \mathrm{C}$, or $10000 \times \mathrm{g}$ at $23^{\circ} \mathrm{C}$ ). The washed resin was suspended in Laemmli loading buffer ( $70 \mu \mathrm{L}$ per sample), and the samples were heated to $95^{\circ} \mathrm{C}$ for $6 \mathrm{~min}$. A Tris-glycine mini gel $(4-20 \%, 12$-well) was loaded with $15 \mu \mathrm{L}$ per lane of the denatured protein mixture. The protein samples were electroeluted $\left(1 \mathrm{~h}, 23^{\circ} \mathrm{C}, 150 \mathrm{~V}\right)$, then transferred under semi-dry conditions to a nitrocellulose membrane $\left(100 \mathrm{~mA}, 23^{\circ} \mathrm{C}, 12 \mathrm{~h}\right)$. The membrane was blocked for $1 \mathrm{~h}(40 \mathrm{~mL}$ $3 \%$ low fat milk in TBS buffer with $0.1 \%$ Tween-20), then rinsed (two ten min washes with TBS buffer containing $0.1 \%$ Tween-20), and treated $1 \mathrm{~h}$ with primary antibody solution (20 $\mathrm{mL}$ of $1 \%$ low fat milk in TBS buffer with $0.1 \%$ Tween-20, containing $10 \mu \mathrm{g}$ of mouse antiB23 antibody). The membrane was rinsed again (two 10-min washes with $40 \mathrm{~mL}$ TBS buffer containing $0.1 \%$ Tween-20) and treated with secondary antibody solution $(20 \mathrm{~mL}$ of $1 \%$ lowfat milk in TBS buffer with $0.1 \%$ Tween-20, containing $20 \mu \mathrm{g}$ of goat anti-mouse-HRP conjugate). The membrane was rinsed once more (three ten min washes with $40 \mathrm{~mL}$ TBS buffer containing $0.1 \%$ Tween-20) and treated with $6 \mathrm{~mL}$ of a $1: 1$ mixture of stabilized peroxide solution:enhanced luminol solution for 3 min prior to visualization.

\section{K. Site-Directed Mutagenesis and Transformation of COS-7 Cells}

Refer to the Supporting Information.

\section{Transfection/Apoptosis Experiments}

HeLa S3 cells were grown to approximately $80 \%$ confluence, then were trypsinized, collected, and pelleted by centrifugation $(10 \mathrm{~min}$ at $183 \times \mathrm{g}$ ). The supernatant was discarded, and the cell pellet was resuspended in fresh medium. The concentration of the cell suspension was determined using a hemacytometer, and a suspension of $1 \times 105$ cells $/ \mathrm{mL}$ was prepared. siPORT NeoFX $(100 \mu \mathrm{L})$ was added to Opti-MEM reduced serum medium $(1900 \mu \mathrm{L})$. A siRNA targeting NPM1.1 (Applied Biosystems, Cat. No. AM16708; ID 143640; $11.4 \mu \mathrm{L}$ from a $50 \mu \mathrm{M}$ stock solution) was added to Opti-MEM $(938.6 \mu \mathrm{L})$. At the same time, a control siRNA 
(Applied Biosystems, Cat. No. AM4611; $11.4 \mu \mathrm{L}$ from a $50 \mu \mathrm{M}$ stock) was similarly added to Opti-MEM $(938.6 \mu \mathrm{L})$. A $950-\mu \mathrm{L}$ aliquot of the diluted NeoFX solution was added to each sample, and the resulting transfection complex solutions were incubated for $10 \mathrm{~min}$ at $23^{\circ} \mathrm{C}$. Cell culture flasks $\left(75 \mathrm{~cm}^{2}\right)$ were charged with $1.8 \mathrm{~mL}$ of the prepared transfection complex solution, followed by $16.2 \mathrm{~mL}$ of the HeLa S3 cell suspension (at $1 \times 10^{5}$ cells $/ \mathrm{mL}$ ). The samples were incubated for $2 \mathrm{~d}$ at $37{ }^{\circ} \mathrm{C}$, under an atmosphere of $5 \% \mathrm{CO}_{2}$. At the end of this period, the cells (which had reached $~ 90 \%$ confluence) were stripped of media, rinsed with trypsin buffer, then detached from the culture flasks by trypsinization $\left(5 \mathrm{~min}, 37^{\circ} \mathrm{C}, 5 \mathrm{~mL}\right.$ per flask, $0.05 \%$ trypsin, $0.53 \mathrm{mM}$ EDTA). Fresh medium $(10 \mathrm{~mL})$ was added, and the resulting suspensions were transferred quantitatively to $50-\mathrm{mL}$ centrifuge tubes. The culture flasks were rinsed with an additional $5 \mathrm{~mL}$ medium, which was likewise added to the centrifuge tubes. The samples were centrifuged $(10 \mathrm{~min}$ at $183 \times \mathrm{g}$ ). The supernatant was discarded, and the cells were resuspended in $30 \mathrm{~mL}$ per sample of fresh medium. The concentration of the cell suspensions was determined using a hemacytometer. Over the course of the $2 \mathrm{~d}$ transfection period, both the transfected and mock-transfected cells grew $\sim 4$-fold. No statistically significant difference in growth rate was observed for the two populations of cells in this experiment, or in several related experiments, using various means of measurement (counting by hemacytometer, assaying cell viability with CellTiter-Blue, and quantifying total protein in lysed cells). 12-well plates were charged with $3 \mathrm{~mL}$ per well of suspensions of the transfected or mock-transfected cells, at $2.5 \times 10^{4}$ cells $/ \mathrm{mL}$. The samples were incubated overnight at 37 ${ }^{\circ} \mathrm{C}$, under an atmosphere of $5 \% \mathrm{CO}_{2}$. The following day, solutions of cell culture medium containing (+)-avrainvillamide (1) or vehicle control were prepared. 500- $\mu \mathrm{L}$ aliquots of these solutions were added to the $3-\mathrm{mL}$ samples. The treated samples were returned to the incubator $\left(37^{\circ} \mathrm{C}, 5 \% \mathrm{CO}_{2}\right)$ for $24 \mathrm{~h}$. The medium (containing any detached cells) from each sample was transferred to a 15 -mL centrifuge tube. The cells were rinsed with $1 \mathrm{~mL}$ PBS, which was added to the centrifuge tubes. Adhered cells were detached from the 12-well plates by trypsinization ( $5 \mathrm{~min}, 37^{\circ} \mathrm{C}, 300 \mu \mathrm{L}$ per sample, $0.05 \%$ trypsin, $0.53 \mathrm{mM}$ EDTA). Fresh medium ( $1 \mathrm{~mL}$ ) was added, and the resulting suspension was added to the centrifuge tubes, along with a $1 \mathrm{~mL}$ rinse (PBS, with $1 \mathrm{mM}$ EDTA and $1 \%$ BSA). The samples were centrifuged (10 min at $183 \times \mathrm{g}$ ), and the supernatant was discarded. The cells from each sample were resuspended in $1 \mathrm{~mL}$ PBS (containing $1 \mathrm{mM}$ EDTA and $1 \% \mathrm{BSA}$ ), transferred to a $1.7-\mathrm{mL}$ centrifuge tube, and centrifuged again $(5 \mathrm{~min}$ at $500 \times \mathrm{g}$ ). The supernatant was discarded, and the samples were cooled on ice. Apoptosis detection buffer $(500 \mu \mathrm{L})$ was added to each sample. The resulting suspensions were mixed and incubated on ice for $1 \mathrm{~h}$, prior to analysis. Each sample was analyzed on an LSRII flow cytometer, with 20,000 events recorded per sample. Apoptotic cells were defined as those permeable to Yo-Pro iodide, but not to propidium iodide (PI). Viable cells were defined as those permeable to neither die. Compensation controls were set manually, to achieve the greatest distinction between viable and apoptotic cell populations (PI vs. YoPro: $30 \%$; Yo-Pro vs. PI: $2 \%$ ). The experiment was carried out three times, with qualitatively similar results obtained each time. Attempts to replicate these results with a second siRNA (Applied Biosystems, Cat. No. AM16708; ID 284660) were unsuccessful; Western-blotting experiments suggest that this siRNA afforded less complete suppression of nucleophosmin (Figure S4).

\section{Effect of (+)-Avrainvillamide Incubation on p53/Nucleophosmin}

Similar drug-treatment, lysis and Western-blotting conditions to those outlined above were used. All samples were incubated for $24 \mathrm{~h}$ at $37^{\circ} \mathrm{C}$, under an atmosphere of $5 \% \mathrm{CO}_{2}$. Full experimental details are provided in the Supporting Information.

\section{Supplementary Material}

Refer to Web version on PubMed Central for supplementary material. 


\section{Acknowledgements}

We are grateful to Alan Saghatelian and members of his research group for assistance with the mutagenesis experiments, and for helpful discussions. We also thank Ross Tomaino for protein sequencing, Seth Herzon for a gift of (-)-avrainvillamide (ent-1), and the Bauer Center for Genomics Research for the use of equipment. We gratefully acknowledge the Natural Sciences and Engineering Research Council of Canada (J.E.W.) and the Swiss National Science Foundation, the Roche Research Foundation, and the Novartis Stiftung (R.S.) for fellowship support. This work was supported by a grant from the NIH (R01 CA047148).

\section{References}

1. Isolation of (+)-avrainvillamide: (a) Fenical W, Jensen PR, Cheng XC. Avrainvillamide, a Cytotoxic Marine Natural Product, and Derivatives Thereof. US Patent 6,066,635. 2000 (b) Sugie Y, Hirai H, Inagaki T, Ishiguro M, Kim YS, Kojima Y, Sakakibara T, Sakemi S, Sugiura A, Suzuki Y, Brennan L, Duignan J, Huang LH, Sutcliffe J, Kojima N. J Antibiot 2001;54:911-916. [PubMed: 11827033]

2. Isolation of the related alkaloid stephacidin B: (a) Qian-Cutrone J, Krampitz KD, Shu Y-Z, Chang LP, Lowe SE. Stephacidin Antitumor Antibiotics. US Patent 6,291,461. 2001 (b) Qian-Cutrone J, Huang S, Shu YZ, Vyas D, Fairchild C, Menendez A, Krampitz K, Dalterio R, Klohr SE, Gao Q. J Am Chem Soc 2002;124:14556-14557. [PubMed: 12465964]

3. Wulff JE, Herzon SB, Siegrist R, Myers AG. J Am Chem Soc 2007;129:4898-4899. [PubMed: 17397160]

4. Myers AG, Herzon SB. J Am Soc 2003;125:12080-12081.

5. (a) Chan WY, Liu QR, Borjigin J, Busch H, Rennert OM, Tease LA, Chan PK. Biochemistry 1989;28:1033-1039. [PubMed: 2713355] (b) You BJ, Huang IJ, Liu WH, Hung YB, Chang JH, Yung BYM. Naunyn-Schmiedeberg's Arch Pharmacol 1999;360:683-690.

6. (a) Bertwistle D, Sugimoto M, Sherr CJ. Mol Cell Biol 2004;24:985-996. [PubMed: 14729947] (b) Kurki S, Peltonen K, Latonen L, Kiviharju TM, Ojala PM, Meek D, Laiho M. Cancer Cell 2004;5:465475. [PubMed: 15144954]See also reference 13

7. (a) Falini B, et al. N Engl J Med 2005;352:254-266. [PubMed: 15659725] (b) Falini B, Nicoletti I, Martelli MF, Mecucci C. Blood 2007;109:874-885. [PubMed: 17008539]

8. Dalenc F, Drouet J, Ader I, Delmas C, Rochaix P, Favre G, Cohen-Jonathan E, Toulas C. Int J Cancer 2002;100:662-668. [PubMed: 12209603]

9. (a) Duyster J, Bai RY, Morris SW. Oncogene 2001;20:5623-5637. [PubMed: 11607814] (b) Turner SD, Alexander DR. Leukemia 2005;19:1128-1134. [PubMed: 15902287]

10. Redner RL, Rush EA, Faas S, Rudert WA, Corey SJ. Blood 1996;87:882-886. [PubMed: 8562957]

11. Yoneda-Kato N, Look AT, Kirstein MN, et al. Oncogene 1996;12:265-275. [PubMed: 8570204]

12. Berger R, Busson M, Baranger L, Hélias C, Lessard M, Dastugue N, Speleman F. Leukemia 2006;20:319-320. [PubMed: 16341035]

13. For leading references, see: (a) Grisendi S, Mecucci C, Falini B, Pandolfi PP. Nature Rev Cancer 2006;6:493-505. [PubMed: 16794633] (b) Naoe T, Suzuki T, Kiyoi H, Urano T. Cancer Sci 2006;97:963-969. [PubMed: 16984370] (c) Lim MJ, Wang XW. Cancer Detect Prev 2006;30:481490. [PubMed: 17113241] (d) Frehlick LJ, Eirín-López JM, Ausió J. BioEssays 2006;29:49-59. [PubMed: 17187372] (e) Gjerset RA. J Mol Hist 2006;37:239-251.

14. (a) Colombo E, Marine J-C, Danovi D, Falini B, Pelicci PG. Nature Cell Biol 2002;4:529-533. [PubMed: 12080348] (b) Maiguel DA, Jones L, Chakravarty D, Yang C, Carrier F. Moll Cell Biol 2004;24:3703-3711.

15. Szebeni A, Herrera JE, Olson MOJ. Biochemistry 1995;34:8037-8042. [PubMed: 7794916]

16. Chan HJ, Weng JJ, Yung BYM. Biochem Biophys Res Commun 2005;333:396-403. [PubMed: 15950182]

17. Hollstein M, Sidransky D, Vogelstein B, Harris CC. Science 1991;253:49-53. [PubMed: 1905840]

18. For drug development candidates targeting p53-regulating proteins, see: (a) Vassilev LT, Vu BT, Graves B, Carvajal D, Podlaski F, Filipovic Z, Kong N, Kammlott U, Lukacs C, Klein C, Fotouhi N, Liu EA. Science 2004;303:844-848. [PubMed: 14704432] (b) Peng Z. Hum Gene Ther 2005;16:1016-1027. [PubMed: 16149900] 
19. In addition to the peptide ligand discussed in references 15 and 16, actinomycin D (and related compounds) may bind to nucleophosmin. See: Busch RK, Chan PK, Busch H. Life Sci 1984;35:1777_ 1785. [PubMed: 6207410]

20. Several cytotoxic compounds are known to cause translocation of nucleophosmin from the nucleolus to the nucleoplasm or to the cytoplasm, but a direct interaction has not generally been inferred. See: (a) Chan PK. Expt Cell Res 1992;203:174-181. (b) Lee HZ, Wu CH, Chang SP. Int J Cancer 2005;113:971-976. [PubMed: 15514966] (c) Yung BYM, Busch H, Chan PK. Cancer Res 1986;46:922-925. [PubMed: 3940652] (d) Chan PK, Aldrich MB, Yung BYM. Cancer Res 1987;43:3798-3801. [PubMed: 2439199]

21. The S-glutathionylation of nucleophosmin has been reported, but the cysteine residue involved in this transformation was not determined. See: Townsend DM, Findlay VJ, Fazilev F, Ogle M, Fraser J, Saavedra JE, Ji X, Keefer LK, Tew KD. Molec Pharm 2006;69:501-508.

22. Nucleophosmin has been identified as a receptor for phosphatidylinositol lipids, which may contribute to its regulatory activity. See: Ye K. Cancer Biol Ther 2005;4:918-923. [PubMed: 16103750]

23. In contrast to the parent protein nucleophosmin, several inhibitors of the hybrid oncoprotein NPMALK have been identified, but these presumably act upon the kinase domain. For a recent example, see: Galkin AV, et al. Proc Nat Acad Sci USA 2007;104:270-275. [PubMed: 17185414]

24. Herzon SB, Myers AG. J Am Chem Soc 2005;127:5342-5344. [PubMed: 15826171]

25. Attempted immunofluorescence and immunoprecipitation experiments using an antibody targeting the dansyl group were not successful, which may indicate that the dansyl group of the conjugate 4 is not recognized by the antibody, at least in its bound state.

26. The correlation is not exact; for example, it appears that compound 11 is a slightly better inhibitor in the affinity-isolation of nucleophosmin than compound 10, although 10 is a more potent inhibitor of T-47D cell growth. This may well reveal the weakness of the underlying assumption that 10 and 11 will function equivalently in the many determinants of a measured $\mathrm{GI}_{50}$ value (lipophilicity, transport, metabolism, etc.), which is not surprising.

27. We have also identified an interaction in live cells between probe 3 and the endoplasmic reticulum protein CLIMP-63. See: Myers A. G.; Herzon, S. B.; Wulff, J. E.; Siegrist, R.; Svenda, J.; Zajac, M. A. Synthesis of Avrainvillamide, Stephacidin B, and Analogues Thereof. International PCT Application, PCT/US2006/009749. 2006. Affinity-isolation experiments suggest that binding between probe 3 and CLIMP-63 is most pronounced after long incubation times ( $2 \mathrm{~d})$. Preliminary experiments suggest that probes 3 and 5 do not display differential affinities for CLIMP-63.

28. The observed difference in antiproliferative activity between (+)-1 and ent-(-)-1 appears to depend upon the assay conditions employed. In our previous report, ${ }^{3}$ we made use of a 48 -h incubation period, followed by detection with the MTS/PMS assay system. Under those conditions, (+)-1 was $\sim 9$-fold more potent than the unnatural enantiomer. In the assay used here (72-h incubation period, followed by CellTiter-Blue detection), (+)-1 was only $\sim 3$-fold more potent than ent-(-)-1.

29. (a) Namboodiri VMH, Akey IV, Schmidt-Zachmann MS, Head JF, Akey CW. Structure 2004;12:2149-2160. [PubMed: 15576029]Lee, HH.; Kim, HS.; Kang, JY.; Lee, BI.; Ha, JY.; Yoon, HJ.; Lim, SO.; Jung, G.; Suh, SW. 2007. in press. Structure available at http://www.pdb.org/pdb/explore.do?structureId=2P1B (c) Herrera JE, Correia JJ, Jones AE, Olson MOJ. Biochemistry 1996;35:2668-2673. [PubMed: 8611572]

30. The cDNA for NPM1.3 was generated from isolates of a human large-cell lung carcinoma. Strausberg RL, et al. Proc Natl Acad Sci USA 2002;99:16899-16903. [PubMed: 12477932]

31. Open Biosystems. Huntsville, AL 35806.

32. There is some confusion in the literature regarding the naming of this transcriptional variant of nucleophosmin. We use the convention of reference 13(c) in referring to this mutant, lacking alternate inframe exon 8 (Gene Bank accession \# NM_199185), as variant 3.

33. Hingorani K, Szebeni A, Olson MOJ. J Biol Chem 2000;275:24451-24457. [PubMed: 10829026]

34. Ventura A, Kirsch DG, McLaughlin ME, Tuveson DA, Grimm J, Lintault L, Newman J, Reczek EE, Weissleder R, Jacks T. Nature 2007;445:661-665. [PubMed: 17251932]

35. Roswell Park Memorial Institute culture medium, series 1640. For formulation, see: Moore GE, Gerner RE, Franklin HA. JAMA 1967;199:519-524. [PubMed: 4960081]

36. Bradford MM. Anal Biochem 1976;72:248. [PubMed: 942051] 


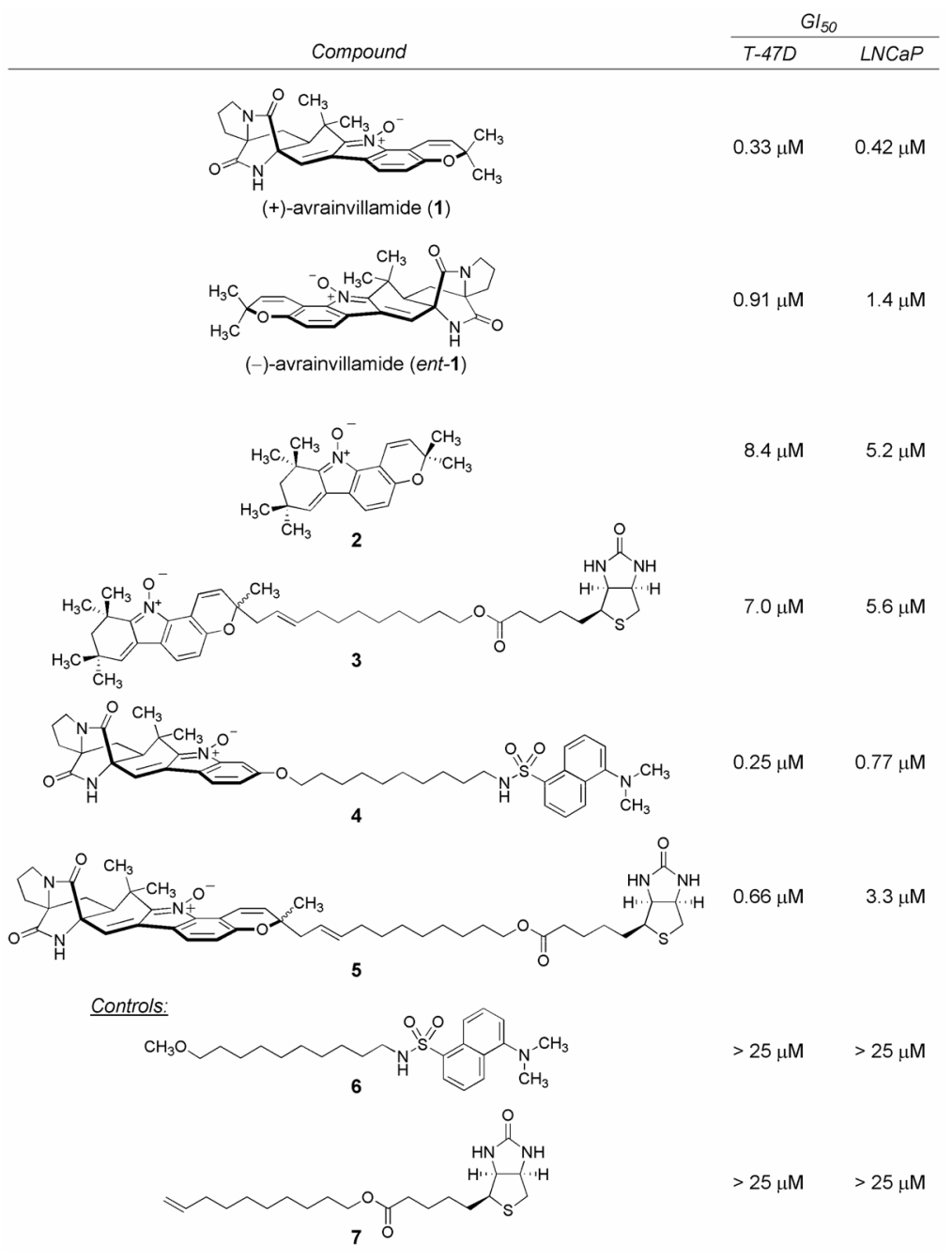

Figure 1.

Structures and antiproliferative activities of inhibitors, activity-based probes and control compounds. 


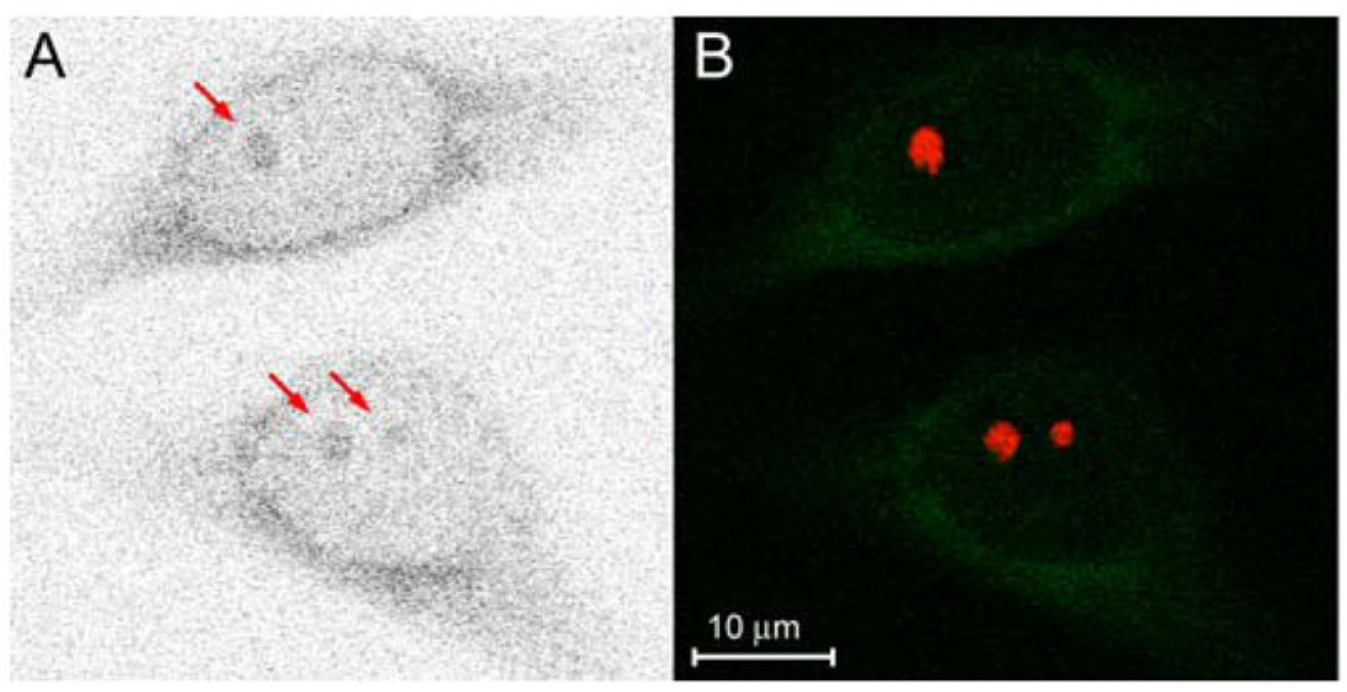

Figure 2.

Images from fluorescence microscopy experiments with HeLa S3 cells incubated for $2 \mathrm{~h}$ at 37 ${ }^{\circ} \mathrm{C}$ in medium containing $1 \mu \mathrm{M}$ probe 4 , then fixed in methanol. (A) Direct fluorescence observed upon irradiation with $365 \mathrm{~nm}$ light, attributed to excitation of the dansyl group of probe 4. (B) Overlay of direct fluorescence output (green) with immunofluorescence output from an antibody to nucleophosmin (red), used here as a nucleolar marker. 


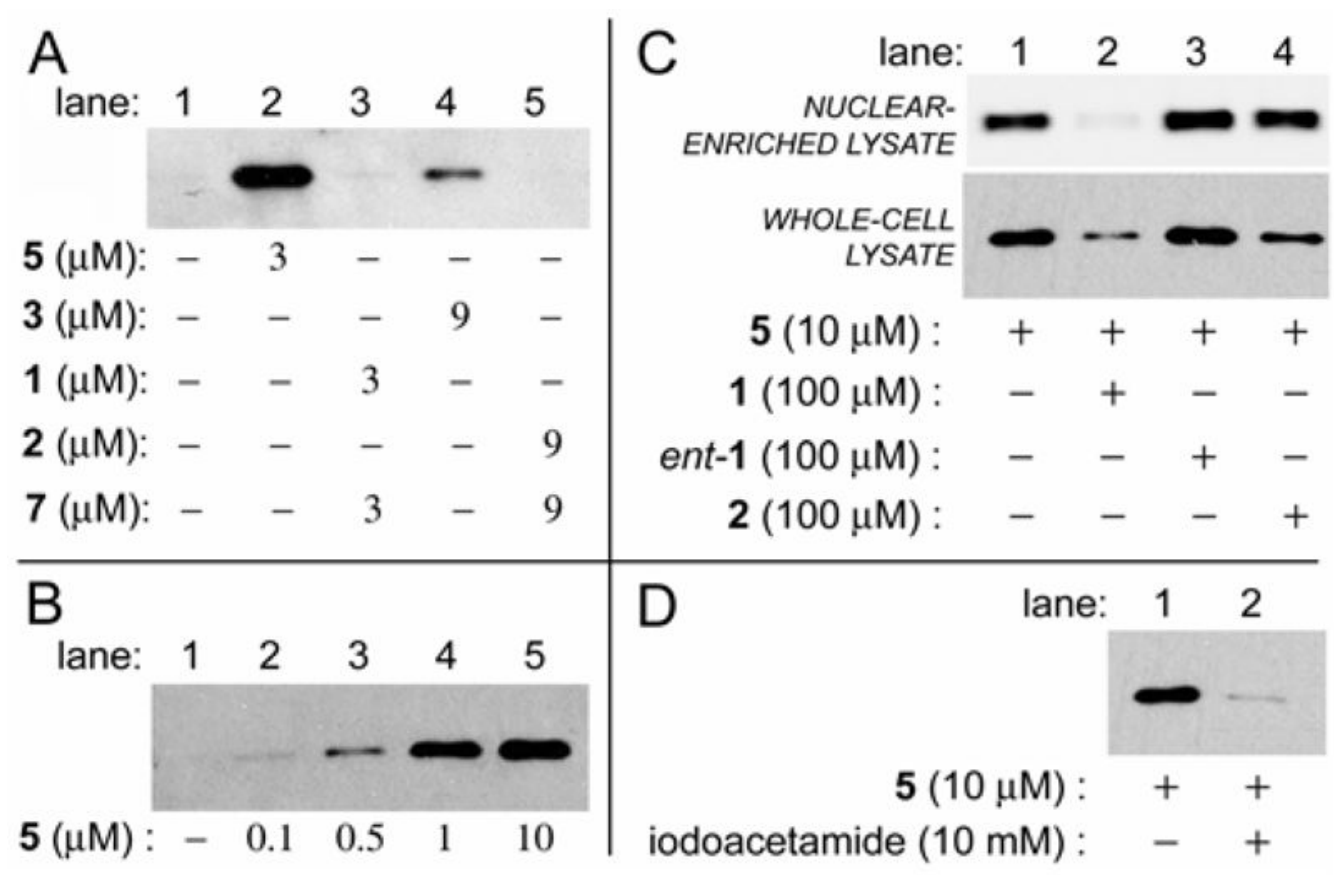

Figure 3.

Western-blot detection of nucleophosmin after affinity-isolation and PAGE. (A) Affinityisolation experiments conducted by incubation of probes with living T-47D cells, then lysis. (B) Affinity-isolation experiments with varying concentrations of probe $\mathbf{5}$ and T-47D wholecell lysates. (C) Competitive binding studies between the probe $\mathbf{5}$ and (+)-avrainvillamide (1), (-)-avrainvillamide (ent-1) or the analogue 2. (D) Affinity-isolation in the absence and presence of iodoacetamide. 

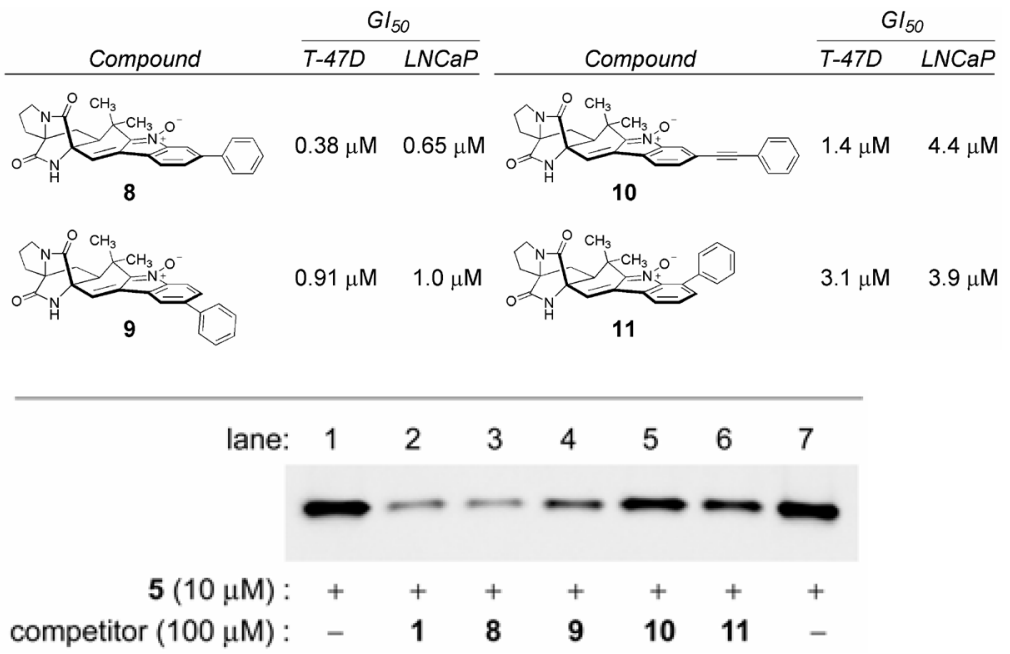

Figure 4.

Western-blot detection of nucleophosmin after affinity-isolation from T-47D nuclear-enriched lysate in the presence of the probe $\mathbf{5}$ and members of a series of closely related structural analogues of avrainvillamide (1) as competitive binders. The ability of the various compounds to block binding of the probe $\mathbf{5}$ to nucleophosmin in this experiment parallels their observed potencies in antiproliferative assays with T-47D cells. 


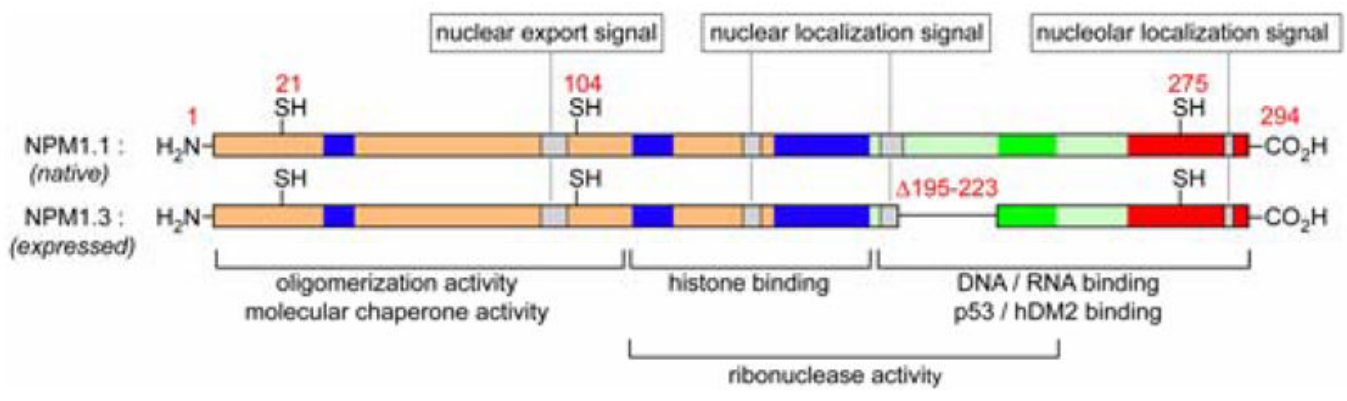

Figure 5.

Cysteine residues and functional domains present within nucleophosmin. ${ }^{33}$ NPM1.1 is observed in live cells and cellular lysates. NPM1.3 is a transcript variant ${ }^{32}$ employed here for site-directed mutagenesis experiments in COS-7 cells (Figure 6). Beige $=N$-terminal non-polar domain, blue $=$ highly acidic regions, light green $=$ moderately basic regions, bright green $=$ highly basic cluster, red $=C$-terminal region, rich in aromatic residues. Nuclear and nucleolar signaling regions are indicated in grey. 


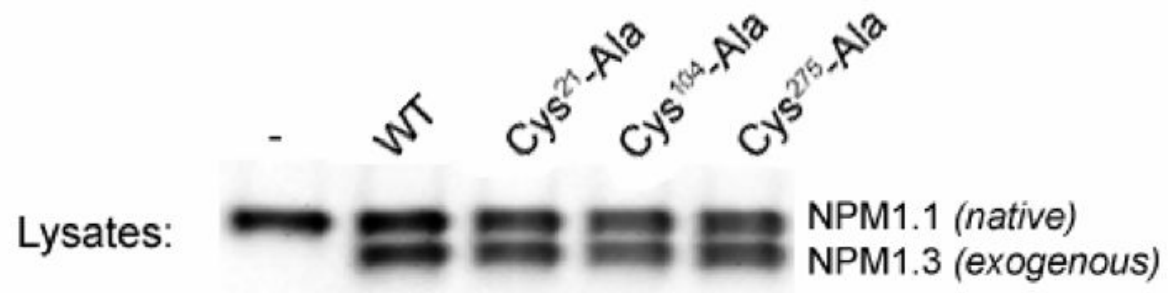

Affinity Isolation:

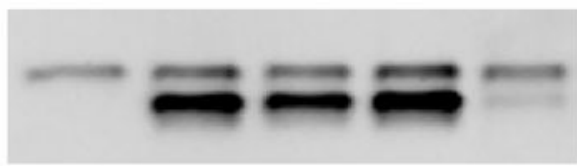

NPM1.1 (native)

NPM1.3 (exogenous)

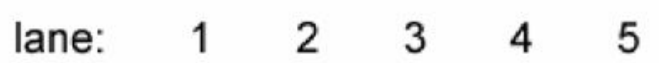

Figure 6.

Western-blot detection of native (NPM1.1) and exogenous (NPM1.3) nucleophosmin in affinity-isolation experiments with $1 \mu \mathrm{M}$ probe 5 . WT $=$ NPM1.3 of unmodified sequence. The presence of native nucleophosmin in the sample lysates constitutes a convenient loading control for the experiment. 

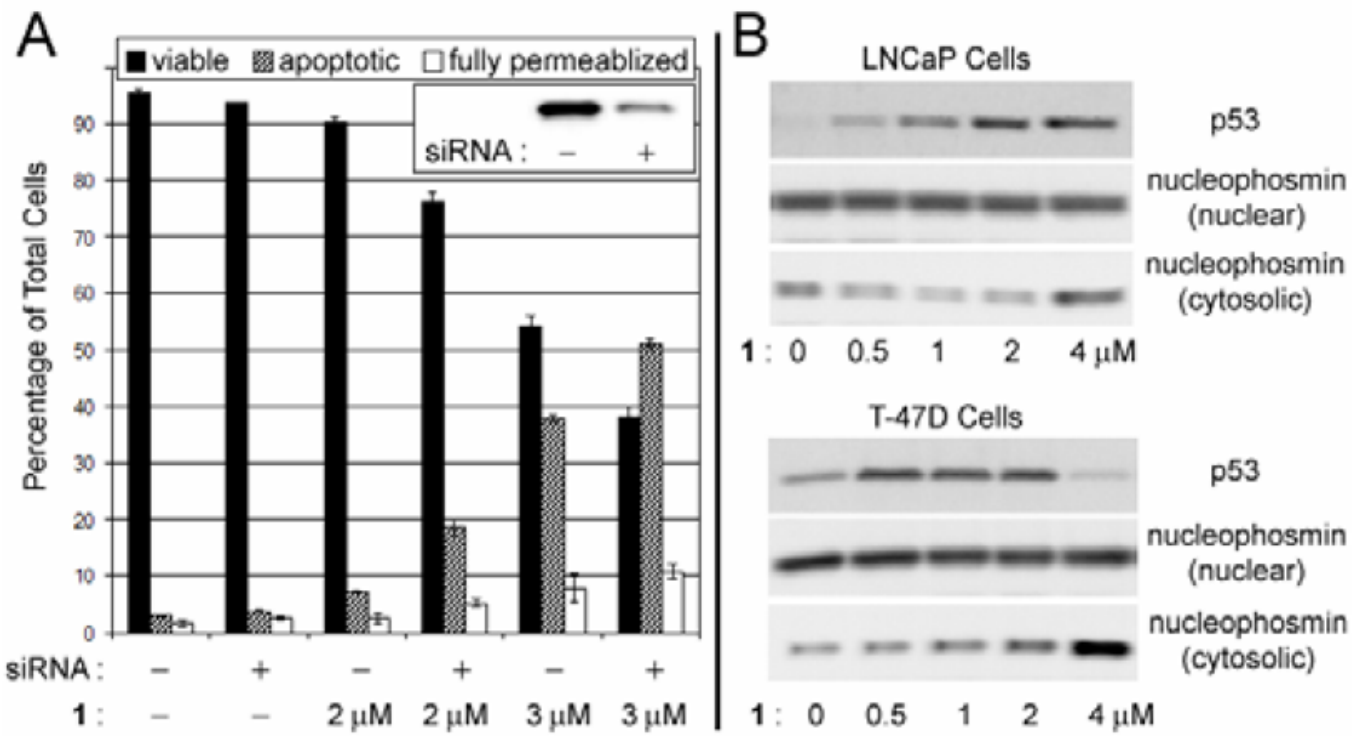

Figure 7.

(A) Increased apoptosis following treatment with (+)-avrainvillamide (1), in HeLa S3 cells depleted in nucleophomsin. Inset $=$ Western-blot detection of nucleophosmin, following transfection. An estimated 75\% depletion in cellular nucleophosmin was observed. (B) Western-blot detection of p53 and nucleophosmin following treatment of live T-47D and LNCaP cells with (+)-avrainvillamide (1) for $24 \mathrm{~h}$. 